УДК 355.33 (477) “1992/2020"

DOI: $10.33099 / 2707-1383-2020-35-1-58-72$

Дрок Л. В., дочент кафедри військової підготовки Національного університету оборони України імені Івана Черняховського ORCID: 0000-0002-2434-4372

\title{
ОСНОВНІ ЕТАПИ ФОРМУВАННЯ ОФІЦЕРСЬКОГО КОРПУСУ ЗБРОЙНИХ СИЛ УКРАЇНИ
}

\begin{abstract}
Дослідження розкриває історичний прочес формування офіцерського потенціалу Збройних Сил Украӥни у період із 1992 року по 2020 рік. У досліджені виділено п'ять етапів формування офіцерського корпусу, проведено аналіз чисельності посад офічерів начіональних Збройних Сил у зазначений вище відтинок часу, з'ясовано сутність тенденцій і пріоритетів діяльності органів державної влади та військового управління в питаннях формування офічерського корпусу у визначених хронологічних рамках.

Наведені результати аналізу чисельності офіцерських посад пояснюють історичні умови, що сприяли становленню професійної складової намої армії - офіцерського корпусу Збройних Сил Украӥни та можуть слугувати виріменню питань щзодо визначення кількісних показників офіцерського складу при побудові сучасного украӥнського війська.
\end{abstract}

Ключові слова: офічерський корпус, чисельність офіџерських посад, Збройні Сили України.

Вступ. За роки незалежності Збройні Сили стали важливим гарантом територіальної цілісності та державного суверенітету України. У боротьбі 3 потужним агресором, що розв'язав "гібридну війну" на Сході держави, сформувалося нове українське військо, керівною і рушійною силою якого виступає офіцерський корпус. У сучасних процесах трансформації української армії висококваліфіковані офіцери є запорукою досягнення амбітної мети - спроможності Збройних
Сил України (далі - ЗС України) взаємодіяти 3 силами Північно-Атлантичного Альянсу. Однак радикальні військові реформи завжди болісно впливають на формування офіцерського корпусу, тому для практичної реалізації комплексу державотворчих заходів і переходу ЗС України на стандарти та критерії НАТО цілком очевидним є знання історії офіцерського корпусу вітчизняних Збройних Сил як фундаменту побудови професійної армії майбутнього. 
Постановка проблеми. Формування офіцерського корпусу завжди $є$ першочерговим та актуальним завданням в процесі будівництва армії. В Україні створення складової військового організму розпочалося після проголошення незалежності держави [1, с. 502]. Протягом неповних тридцяти років історія будівництва українського офіцерського корпусу характеризується позитивними елементами перебудови - запровадження оперативно-територіальної системи підпорядкування, зміни організаційної структури кадрових органів, скорочення чисельності національних Збройних Сил, приведення у відповідність до вимог структури та якості офіцерського складу. Однак ці досягнення були нівельовані загальним низьким станом боєздатності ЗС України на початкових етапах збройної агресії Російської Федерації в 2014 році, що стало результатом непродуманої воєнної політики влади. Одним з основних показників, що визначає боєздатність армії є укомплектованість офіцерських посад у всіх ланках військового управління, тому аналіз динаміки зміни чисельності посад офіцерів українських Збройних Сил являється передумовою вивчення бойових спроможностей військ (сил) та потребує дослідження 3 метою утвердження однієї 3 найважливіших складових військового організму - офіцерського корпусу ЗС України.

Аналіз останніх досліджень і публікацій. На сьогоднішній день існує чималий доробок наукових матеріалів присвячених офіцерському корпусу 3С
України. Вагомий внесок в дослідження історії створення видів Збройних Сил має робота В. Шевчука "Історіографія створення та розвитку Збройних Сил України в 1991-2014 роках", в якій висвітлюється процес нагромадження історичних знань про створення та розвиток ЗС України у 1991-2014 роках $[19$, с. 55]. Науковець О. Покотило розглядав основні тенденції формування українського війська в перші роки незалежності держави, аналізуючи зокрема питання комплектування війська офіцерськими кадрами [16]. I. Сокаль описав зміст організаційних заходів щодо формування засад національної системи протиповітряної оборони, висвітлюючи при цьому функціональну структуру військ Протиповітряної оборони [18]. О. Нашивочніков систематизовано й узагальнено показав кількісний склад та якісний стан Чорноморського флоту на початку 1990-х pp. у своїй дисертаційній роботі [15]. Г. Воробйов розкрив процес створення та розвитку Сухопутних військ України в 1991-2005 pр. описавши особливості добору кадрів на вищі керівні посади 3С України [3]. Доволі значний масив наукових праць було присвячено етапам військового будівництва ЗС України. Певний доробок, присвячений питанням висвітлення в українській військовій пресі XX - початку XXI ст. становлення офіцерського потенціалу Збройних Сил України, знаходимо в роботі С. Сегеди [17]. Періодизацію створення та комплектування вищого офіцерського корпусу ЗС України 
на основі аналізу діяльності кадрових органів 3 питань комплектування посад вищого офіцерського складу створив О. Дашкевич. [5, с. 64]. Історію становлення нормативно-правових документів формування офіцерського складу ЗС України відобразив В. Машталір $[14$, c. 22$]$.

Незважаючи на доволі значний масив наукових праць, присвячених офіцерському корпусу ЗС України, питання формування офіцерського потенціалу вітчизняні вчені розглядали винятково через призму шляхів та завдань будівництва Збройних Сил, залишаючи поза увагою статистичні дані офіцерського корпусу українського війська в період з 1991 по 2020 роки. Крім того, досліджень за вказаною темою у відкритих джерелах не виявлено, відповідно проблема потребує більш глибокого вивчення.

Метою даної статі $\epsilon$ визначення хронологічних рамок етапів формування офіцерського корпусу ЗС України, проведення аналізу зміни чисельності офіцерських посад та розгляд їх динаміки в інтервалі 1991-2014 pp, а також з'ясування взаємозв'язку між статистичними даними та проблемами, що виникали в процесі будівництва офіцерського корпусу.

Виклад основного матеріалу дослідження. Для розробки стратегії формування оптимальної структури офіцерського корпусу сучасних Збройних Сил не достатньо організаційних та управлінських реформ, необхідно творчо врахувати успіхи та прорахунки процесу в історичній ретроспективі реформування ЗС України, змоделювати можливі варіанти побудови та функціонування структури, спираючись на достовірні статистичні дані та практичні і наукові напрацювання.

Вирішення поставленої мети статті грунтується на застосуванні статистичного методу досліджень та історичного методу. Метод періодизації спрямований на розкриття внутрішньої часової побудови процесу, дозволяє зрозуміти розвиток історичного процесу в рамках досліджуваного об'єму даних, систематизувати факти та типові події, визначити якісно нові змістовні характеристики індикатора переходу однієї стадії в другу [2, с. 96]. Відповідно до правила однакових підстав при виділенні рівних за таксономічною значимістю періодів у побудові історичної періодизації необхідно виділяти однакові критерії [11, с. 392], тому в досліджені систематизація кількісного показника чисельності офіцерських посад по роках дає право визначити хронологічні рамки етапів формування офіцерського корпусу ЗС України, з'ясувати взаємозв'язок між статистичними даними та основними проблемами будівництва офіцерського корпусу. В свою чергу статистичний метод розкриває можливості вивчення динаміки змін чисельності офіцерських посад на певному інтервалі, що, безсумнівно, є основою для систематизації обраного критерію.

3 метою практичного виконання дослідження створено базу даних чисельності посад офіцерів ЗС України протягом визначених хронологічних рамок. 
Для з'ясування динаміки змін чисельності офіцерських посад та аналізу іiі характеру визначено різницю кількості посад за роками. Дану різницю представлено у відсотковому відношенні. Рисунок 1 відображає динаміку змін кількості посад офіцерів у відсотках. Отриманні результати дослідження дозволяють розділити період функціонування ЗС України з 01.01.1992 по 01.01.2020 на певні етапи формування офіцерського корпусу.

Окремо автором розглядається інтервал 1991 - 1992 рр. як перехідний етап у створенні національних Збройних Сил $\mathrm{i}$ офіцерського корпусу зокрема.

Аналізуючи законодавство України у воєнній сфері протягом 1991 - 1992 рр., можна встановити логічну послідовність впровадження законодавчих актів державотворчих органів стосовно формування офіцерського корпусу. Так прийняттям Постанови Верховної Ради України "Про військові формування на Україні" від 24 серпня 1991 року № 1431-XII започатковано будівництво 3С України шляхом підпорядкування всіх військових формувань Збройних Сил СРСР на території республіки, Верховній Раді України. Затвердження " Концепції оборони і будівництва Збройних Сил України” від 11 жовтня 1991 року № 1659-XI та Закону України "Про Збройні Сили України” від 6 грудня 1991 року № 1934-XII впроваджували тривидову структуру Збройних Сил (Сухопутні війська, Військово-Повітряні Сили і Сили Протиповітряної оборони, Військово-Морські Сили) та визначали органи військового управління. Ухвалений Закон України "Про оборону України" від 6 грудня 1991 року № 1932-XII структурував Збройні Сили на військові об'єднання, з'єднання, частини, підрозділи, військові установи і навчальні заклади. Тимчасове положення про Міністерство оборони України (далі МОУ), що було затверджене Постановою Кабінету Міністрів України від 20 листопада 1991 р. № 321, окреслювало дії відомства стосовно чисельності особового складу видів і родів військ, організаційно-штатної структури військ, підготовки та розстановки військових кадрів, призову та звільнення в запас військовослужбовців. Указ Президента України “"Про невідкладні заходи по будівництву Збройних Сил України" від 5 квітня 1992 року № 209 визначав МОУ завдання з формування Військово-Морських Сил України та органів їх управління. Постанова Верховної Ради України "Про текст Військової присяги" від 6 грудня 1991 року № 1936-ХІІ започаткувала з січня 1992 року процес приведення до добровільної присяги на вірність народові України дислокованих на українській території військ.

Однак незважаючи на зусилля державних органів та органів військового керівництва щодо впорядкування діяльності військових угрупувань, які розташовувалися на території України, вони являли собою сукупність окремих розрізнених за складом та озброєнням військових структур, що потребували належного управління для забезпечення їх постійної бойової готовності, до- 
тримання військової дисципліни, зменшення соціально-політичної напруги у військах. Ухвалені Закони України та підзаконні акти у воєнній сфері визначали першочергові завдання для урегулювання ситуації та потребували невідкладного рішення - переформатування армійської структури, скорочення чисельності озброєння і особового складу та переміщення військових кадрів.

Виваженими кроками, з урахуванням обмежень Договору "Про звичайні збройні сили в Європі” від 1 липня 1992 року № 2526-XII, потрібно було провести поетапне скорочення чисельності озброєння, військової техніки та особового складу до оптимальної кількості, яка відповідатиме реальній воєнній загрозі, проголошеному статусу позаблокової та без'ядерної держави, ресурсним можливостям та рівню реального фінансування оборонного відомства, сформувати резерв висококваліфікованих кадрів в процесі скорочення, забезпечити формування нового якісного кадрового потенціалу українського війська. Проте громіздка і обтяжлива для бюджету молодої країни оборонна система колишнього СРСР перешкоджала становленню військового угрупування незалежної України та вплинула на тривалість процесу будівництва ЗС України.

Вирізняються заходи з організаційно-кадрових питань, які не припинялися впродовж кількох років. Так з метою створення Військ наземної оборони Указом Президента України "Про розформування Київського військового округу” від 16 жовтня 1992 року № 497 об'єднання, з'єднання, військові частини що входили до складу округу, а це близько 150 тис. військовослужбовців підлягали скороченню, звільненню в запас чи виведенню у розпорядження Міністра оборони України, з 3 січня 1992 року Одеський військовий округ перейшов під юрисдикцію України i був включений до складу Сухопутних військ ЗС України угрупуванням 110 тис. військових та службовців що теж підпадали під радикальні організаційні реформи. Утворення Військово-Повітряних Сил України проведено згідно 3 директивою Начальника Головного штабу ЗС України від 17 березня 1992 року, за результатом якої когорта авіаторів в 120 тис. зазнавали переформування. Формування органів управління Військово-Морських Сил України було розпочато 3 виданням Указу Президента України від 5 квітня 1992 року "Про перехід Чорноморського флоту в адміністративне підпорядкування Міністерству оборони України", однак створення військового флоту було складним та довготривалим і лише 31 травня 1997 року Угода про статус i умови перебування Чорноморського флоту Росії на території України поставила крапку в процесі перебудови [12, c. 52-54].

Практична робота органів кадрового забезпечення з питань переводу військових до України спиралася на законодавчі і відомчі нормативно-правові документи - Укази Президента України від 24 березня 1992 року № 189 та від 1 грудня 1992 року № 590 “О возвращении воен- 
нослужащих-граждан Украины из "горячих точек", а також наказ Міністра оборони України від 16 грудня 1992 р. № 216 “Об организации работы по переводу военнослужащих в Вооруженные Силы Украины" [5, с. 66]. Виконання поставлених завдань перехідного етапу заснування офіцерського корпусу національних Збройних Сил підтверджується статистичними даними чисельності офіцерських кадрів. На початок 1992 року в ЗС України було 186598 офіцерів $(25,68 \%)$ при загальній чисельності 726536 військовослужбовців і 180 тис. працівників [5, с. 65]. Станом на грудень 1992 року було подано 36836 рапортів про переведення, відіслано 20999 списків-клопотань у кадрові органи СНД про переведення. Тільки в Російській Федерації 7 тис. військових чекали згоди на повернення в Україну. Значна частина військових повернулася з-за кордону, зокрема Україна прийняла 7,2 \% особового складу, який виводився із Західної групи військ [13, с. 98]. За період 1991 - 1994 pp. для проходження служби до України повернулися 27982 офіцерів з військових частин, дислокованих на територіях Азербайджану, Вірменії, Молдови, Груsii, Таджикистану.

В подальшому загальні засади проходження військової служби офіцерським складом 3С України упорядковувалися Законом України "Про військовий обов'язок і військову службу", прийнятим Постановою Верховної Ради України від 25 березня 1992 року № 2233-XII. Прикладні заходи у вирішенні завдань комплектування офіцер- ськими кадрами започатковано Указами Президента України від 13 травня 1993 року № 174 “"Про тимчасові положення про проходження служби громадянами України” та від 7 жовтня 1993 р. № 429 "Про продовження дії статті 2 Указу Президента України від 13 травня 1993 року", в яких встановлювалися основні умови проходження військової служби офіцерами в українській армії [5, с. 66].

Безпосереднє виконання кроків по підбору, розстановці офіцерських кадрів Постановою Кабінету Міністрів України "Про визначення структури Центрального апарату Міністерства оборони України" від 20 листопада 1991 року № 321 покладалося на управління кадрів МОУ [4, с. 2].

Таким чином, характерними ознаками перехідного етапу створення офіцерського корпусу ЗС України є формування конституційних засад політики у сфері оборони і національної безпеки, прийняття законодавчих актів стосовно забезпечення національної безпеки та оборонної політики, впровадженням правової основи регулювання будівництва та реформування 3С України, формування структури та чисельності військ, створенням відповідних систем військового управління, підготовки i всебічного забезпечення військ, напрацювання та впровадження нормативноправової бази службової діяльності в структурах Збройних Сил.

Подальший проміжок названо етапом “становлення" формування офіцерського корпусу 3С України та охоплює відрізок часу з 01.01.1992 по 01.01.1996 pp. 
Скорочення за перший рік “становлення” досягло 38,1 \% від загальної чисельності офіцерських посад, стало переломним моментом у розбудові національного війська та було зумовлено великим надлишком посад офіцерів, які залишилися у спадок від армії СРСР, перенасиченням структури ЗС України особовим складом (див. рис 1).

Управління кадрів МОУ розпочало обліковувати офіцерів, які проходили військову службу у ЗС України, лише у 1992 році. Наказ по управлінню кадрів від 12 травня 1992 року визначав функції та завдання структури, покладав обов'язки щодо підбору і розстановки офіцерських кадрів на 1 та 5 відділи $[8$, c. 1]. Окрему організаційно-штатну складову Головного управління кадрів MOУ, що займалася обліком та статистикою штатів, в архівних документах виявлено в 1999 році [9, с. 47].

Інтервалу, що охоплює 1994 - 1995 pp. притаманна стабілізація активності процесу зменшення чисельності офіцерських посад, однак наступний рік мав тенденцію до підвищення на 7,2 \% (див. рис. 1). За п'ять років етапу становлення чисельність військ скорочено на 410 тис. військових та службовців, розформовано 3500 військових структур [6, с. 194].

Таким чином, на даному етапі реформування офіцерського корпусу проводилося без моделювання майбутньої структури Збройних Сил, супроводжувалося масштабним скороченням чисельності озброєння, військової техніки, персоналу. Ситуацію ускладнювали відсутність прикладних напрацювань щодо структури та співвідношень категорій офіцерського корпусу.

Другий етап формування офіцерського корпусу 3С України охоплює інтервал з 01.01.1996 по 01.01.2005 pp. та названо етапом "формування нової структури".

Даний відрізок охоплює великий проміжок часу в історії української армії, для якого характерно подальше нарощування темпів зменшення чисельності посад офіцерів. В середньому динаміка складала 3,35 \% за рік. В результаті необгрунтованого урізання чисельності Збройних Сил розпочався процес системного зниження рівня боєздатності армії. Даний висновок спирається на орієнтовний критичний показник звільнення персоналу протягом року - 5 \%. При перевищенні цифрового значення військова структура зазнає професійних втрат, а приведення до оптимального рівня (навчання, введення в стрій, перенавчання) вимагає тривалого кількарічного періоду відновлення [7, с. 129]. Підтвердженням цього $є$ різниця показника кількості посад офіцерів, виражена у відсотках (див. рис.1).

3 іншого боку, під час “формування нової структури” було вирішено ряд проблем, що мали як позитивний, так i негативний вплив на формування офіцерського корпусу 3С України, а саме:

запроваджено військово-адміністративний поділ території держави $[5$, c. 68$]$;

проведено структурну реформу Збройних Сил (перехід від об’єднань, 
3'єднань на бригадно-батальйонну структуру) [12, с. 55];

відбулося становлення системи військової освіти [6, с. 201];

удосконалено організаційно-штатну структуру кадрових органів щодо підбору, розстановки, обліку офіцерів $[10$, c. 2$]$;

впроваджено значну кількість директив, наказів військового керівництва з урегулювання соціальних питань, зокрема грошового забезпечення;

доопрацьовано відомчу нормативно-правову базу всіх ланок військового управління щодо упорядкування повсякденної діяльності військ.

Таким чином, на даному етапі військове керівництво держави визначило спрямування на становлення організаційно-штатної структури української армії, удосконалення ефективного управління військовими частинами та установами, створення умов для розбудови оптимальних за чисельністю, мобільних, всебічно оснащених, навчених, необтяжливих для оборонного бюджету країни Збройних Сил. Але досягти цього не вдалося, процес системного зниження рівня боєздатності війська поглибився.

Третій етап формування офіцерського корпусу ЗС України охоплює проміжок з 01.01.2005 по 01.01.2009 pp., його та названо етапом "стандартизаціï”. На цьому етапі щорічний показник чисельності офіцерських посад показував стійке зменшення, середньорічна динаміка скорочення становила 1,92 \% (див. рис 1).
Варто охарактеризувати третій етап тим, що воєнно-політична орієнтація керівництва держави зазнала суттєвих змін в контексті подальшого розвитку українського війська. Було визначено ключовим напрямом реформи Збройних Сил досягнення стандартів Північно-Атлантичного Альянсу, разом 3 тим, відповідно до Державної програми розвитку Збройних Сил України на 2006 - 2011 рр. реформування української армії передбачало істотні переформатування системи військового управління, оперативного планування, підготовки, бойової і мобілізаційної готовності, матеріально-технічного забезпечення військ (сил) [12, с. 58]. У загальному підсумку реформи армії зосередилися на запроваджені контрактного принципу комплектування особовим складом, скороченні потреби в забезпеченні особовим складом, матеріально-технічними й мобілізаційними ресурсами, оновленні нормативно-правової бази діяльності військових структур в умовах скорочення чисельності особового складу в 2005 2007 pр., уточненні доктринальних документів щодо організації підготовки та застосування ЗС України. Водночас даному проміжку властиві прогнозованість та передбачуваність. Характер скорочення посад офіцерів грунтується на виваженій плановості, що підтверджується низьким річним приростом показника скорочення посад офіцерів (1,92\%), а низькі темпи впровадження контрактного принципу комплектування та застосування для проведення ка- 
дрової реформи моделей збройних сил США, країн НАТО уповільнюють хід процесу.

Четвертий етап формування офіцерського корпусу ЗС України тривав із 01.01.2009 по 01.01.2014 рр. та отримав назву етапу “тотального скорочення".

Це один із найскладніших відрізків часу функціонування національних Збройних Сил, який характеризується ігноруванням з боку керівництва МОУ та вищого військового командування основних положень теорії воєнного мистецтва, досвіду раніше досягнутих результатів реформування ЗС України.

На даному проміжку формуванню офіцерського корпусу військове керівництво держави зовсім не надавало уваги. Офіцерські посади, а іноді військові частини в цілому скорочувались без будь-яких наукових обгрунтувань, разом 3 тим негативно впливали соціально-економічна та політична тенденції в державі, антиукраїнська та проросійська воєнна політика військового керівництва, зацікавленість вищого військового керівництва в матеріальних та фінансових зисках, непрозорий механізм призначення на посади від середньої ланки і вище, бездумне скорочення досвідчених військових фахівців, заміщення військових посад цивільними працівниками, фінансування потреб армії за залишковим принципом тощо. [19, с. 68-69]. На кінець 2013 року скорочення посад офіцерів сягнуло катастрофічних значень - 77,9 \% (див. рис. 1).

П'ятий етап формування офіцерського корпусу ЗС України охоплює час з 01.01.2014 по теперішній час. Його названо етапом “відродження".

Станом на 01.01.2020 року здійснено нарощування на 17,2 \% кількості офіцерських посад у порівнянні 3 вихідним показником на 01.01.2014 року. Скорочення офіцерських посад протягом п'ятого етапу зменшилося в порівнянні із загальною чисельністю офіцерських посад станом на 01.01.1992 року та досягло 60,7 \% (див. рис 1).

Події на Сході нашої держави вимушено зумовили відродження офіцерського корпусу. На даному етапі було вирішено першочергові проблемні питання формування офіцерського складу ЗС України, а саме:

переміщення офіцерів здатних керувати в складних умовах на керівні посади;

призов на військову службу офіцерів запасу під час мобілізації; комплектування офіцерських посад наново сформованих військових частин; призов на військову службу офіцерів запасу, які закінчили військову кафедру.

Таким чином, аналіз перших двох етапів формування офіцерського корпусу ЗС України, а саме етапу “становлення" та етапу “формування нової структури” дозволив правомірно стверджувати, що в період з 1991 по 2005 рік в Україні було створено законодавчу та нормативно-правову базу для формування офіцерського складу національних Збройних Сил.

На сучасному етапі “відродження", в умовах ведення війни на сході нашої держави проти збройної агресії РФ, 
Показники у відсотках

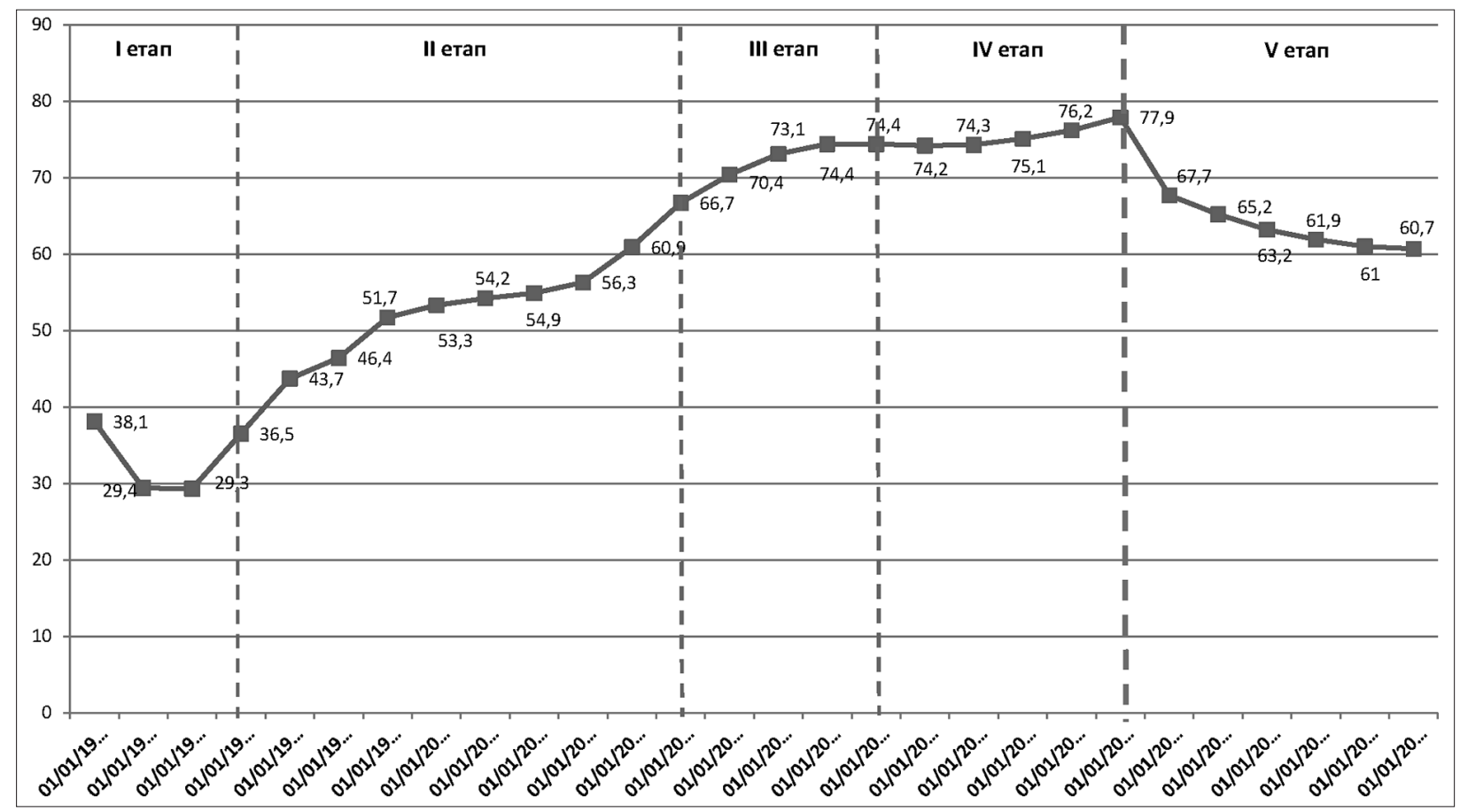

Рис. 1. Динаміка скорочення кількості посад офіцерів у відсотках з 01.01.1992 по 01.01.2020

формування офіцерського корпусу розглядається військовим керівництвом як найважливіша складова військового будівництва, що має за головну мету забезпечення потреб усіх видів збройних сил у навченому, висококваліфікованому офіцерському складі як у мирний, так і у воєнний час. Спрямування процесу реформування та розвитку ЗС України на створення нової моделі оптимальних за чисельністю, мобільних, всебічно оснащених Збройних Сил з урахуванням принципів оборонної достатності, економічних і фінансових можливостей держави, зумовлює необхідність виконання низки заходів щодо підтримання їх бойової готовності через удосконалення та реформування елементів існуючої системи будівництва Збройних Сил, у тому числі і системи комплектування особовим складом, що і $\epsilon$ яскравим відображенням п'ятого ета- пу формування офіцерського корпусу ЗС України - "відродження".

Висновок. Дослідження законодавства України у воєнній сфері, архівних матеріалів та джерел МОУ, наказів i розпоряджень Міністра оборони України, історичних наукових матеріалів дозволило розглянути перебіг подій, пов'язаних із формуванням офіцерського корпусу ЗС України, починаючи від проголошення незалежності у 1991 р. та створення власного оборонного відомства до сучасних процесів трансформації ЗС України. Зокрема, виявлено, що:

проходження служби офіцерами після проголошення незалежності України відбувалося в складних історичних умовах, процес супроводжувався значним зменшенням чисельності особового складу, зокрема офіцерської когорти;

важливою передумовою для вирішення кадрових питань формування 
офіцерського корпусу було визначення перспективних структур 3С України та розроблення і впровадження відповідних штатів з'єднань, об'єднань, установ, військових частин;

намітилися сучасні вимоги порядку проходження військової служби особами офіцерського складу, їх права та обов'язки з урахуванням об'єктивної ситуації, що склалась у військах після проголошення незалежності;

удосконалена організаційно-штатна структура кадрових органів щодо підбору, розстановки, обліку офіцерів визначила особливості кадрового менеджменту з усіма категоріями особового складу з урахуванням специфіки функціонування Збройних Сил;

започатковано розробку нормативно-правової бази кадрового менеджменту ЗС України з урахуванням перспектив Євроатлантичної інтеграції держави, впровадженням стандартів НАТО у військовій сфері, розширенням миротворчої діяльності Збройних Сил;

структурні зміни української армії та флоту зумовили переформатування системи військової освіти України.

На основі проведених досліджень автором встановлено періодизацію процесу формування офіцерського корпусу $3 \mathrm{C}$ України, який можна поділити на $\mathrm{V}$ етапів, окремо виділяючи перехідний відтинок часу 1991-1992 рр.:

- I етап “становлення" з 01.01.1992 по 01.01.1996 pp.;

- II етап "формування нової структури”з 01.01.1996 по 01.01.2005 pр.;
-III етап “стандартизації” 3 01.01.2005 по 01.01.2009 pp.

- IV етап "тотального скорочення" 3 01.01.2009 по 01.01.2014 pp.;

- V етап “відродження”. з 01.01.2014 по теперішній час.

Крім того, створення та статистичний аналіз бази даних чисельності посад офіцерів у визначених хронологічних рамках дозволили розглянути динаміку змін чисельності офіцерських посад, описати їі характер, який полягає у суттєвому їх скороченні на I етапі та подальшому зростанні на II - IV етапах. 3 початку V етапу відсоток офіцерських посад скорочується за рахунок наближення до стандартів НАТО та збільшення відсотку рядового і сержантського складу. Математико-статистичний аналіз дозволив розширити періодизацію етапів формування та становлення офіцерського корпусу ЗС України, що стало принципово новим підходом до визначення проблем формування офіцерського складу ЗС України.

Завдяки проведеній аналітичній роботі окреслено процеси трансформації офіцерського складу наприкінці XX століття та початку нового століття, висвітлено статистичні дані щодо сучасного стану офіцерського складу ЗС України i зображено його перспективи. Подальше дослідження даної проблеми полягає у більш детальному вивченні формування офіцерського корпусу у період з 2014 року донині та моделюванні його перспективної структури. 


\section{Список використаних джерел і літератури}

1. Акт проголошення незалежності України : Постанова Верховної Ради України від 24 серпня 1991 р. № 1427-XII. Відомості Верховної Ради України. 1991. № 38. с. 502. URL: https://zakon. rada.gov.ua/laws/show/1427-12 (дата звернення: 31.03.2020).

2. Бочаров А. В. Основные научные методы в историческом исследовании : учебное пособие. Томск. 2006. $190 \mathrm{c}$.

3. Воробйов Г. П. Створення та розвиток Сухопутних військ Збройних Сил України (1991 2005 рр.) : автореф. дис. ... канд. іст. наук : 20.02.22. Київ, 2014. 18 с.

4. Витяг з історичної довідки Управління кадрів Міністерства оборони України за період 1991 - 1992 рр. ГДА МО України (Галуз. держ. архів Мін. обор. Укр.). Ф. 3501. Оп. 17713. Сп.79.

5. Дашкевич О. І. Метод періодизації як інструмент історичного дослідження діяльності кадрових органів Збройних Сил України з питань комплектування посад вищого офіцерського складу (1991-2011). Воєнно-історичний вісник. Київ. 2012. № 3 (5). С. 62-75.

6. Дашкевич О. І. Вищий офіцерський корпус: історія створення та комплектування : монографія. Вінниця : “ТД “Едельвей і К””, 2015. 285 с.

7. Думенко М. П. Функціонування служб (підрозділів) персоналу Збройних Сил України у 2011 - 2018 роках в умовах мирного часу та особливого періоду. Воєнно-історичний вісник. Київ. 2019. № 34 (4). С. 128-139.

8. Історична довідка за 1991 - 2001 роки. ГДА МО України (Галуз. держ. архів Мін. обор. Укр.). Ф. 3501. Оп. 48085. Сп.136.

9. Книга штатно-посадового обліку офіцерського складу та прапорщиків Головного управління кадрів Міністерства оборони України за 1999 - 2001 рр. ГДА МО України (Галуз. держ. архів Мін. обор. Укр.). Ф. 3501. Оп. 48732. Сп.74.

10. Книга штатно-посадового обліку офіцерського складу та прапорщиків Головного управління кадрів Міністерства оборони України за 2001 - 2004 рр. ГДА МО України (Галуз. держ. архів Мін. обор. Укр.). Ф. 3501. Оп. 48732. Сп. 32.

11. Крадин Н. Н., Коротаев А. В., Гринин Л. Е. Теория и методология истории : учебник для вузов. Волгоград : Учитель, 2014. 504 с.

12. Кузьмук О. І. Еволюція структури Збройних Сил України (1991 - 2011 рр.). Військово-науковий вісник. Львів. 2011. № 16. С. 47-63.

13. Левик Б. С. Військово-політичне забезпечення становлення Збройних Сил України 1991 - 1992 рр. (за матеріалами Державного галузевого архіву Міністерства оборони України). Аналітично-інформаційний журнал “Схід”. Донецьк. 2012. № 3. С.96-102.

14. Машталір В. До історії створення нормативно-правової бази регулювання діяльності офіцерського складу Збройних Сил України. Збірник наукових праць “Питання історії науки і техніки”. Київ : Центр пам’яткознавства НАНУ і УТОПІК. 2009. № 2 (10). С. 22-24.

15. Нашивочніков О. О. Створення основ Військово-Морських Сил України (1991 1994 рр.) : автореф. дис. ... канд. іст. наук : 20.02.22. Київ, 2016. 20 с. 
16. Покотило О. І. Створення Збройних Сил України: історіографія : автореф. дис. ... канд. іст. наук : 20.02.22. Київ, 2012. 20 с.

17. Сегеда С. П. Українська військова преса як чинник національного військового будівництва (XX - початок XXI століття) : автореф. дис. ... д-ра іст. наук : 20.02.22. Київ, 2013. 36 с.

18. Сокаль I. І. Створення системи протиповітряної оборони України (1991 - 2000 pp.): icторичний аспект : автореф. дис. ... канд. іст. наук: 20.02.22. Київ, 2004. 20 с.

19. Шевчук В. П. Історіографія створення та розвитку Збройних Сил України в 1991 2014 роках. Воєнно-історичний вісник. Київ. 2019. № 31 (1).

\section{References}

1. Postanova Verxovnoyi Rady`Ukrayiny`. (1991). Akt progoloshennya nezalezhnosti Ukrayiny` vid 24 serpnya 1991 r. № 1427-XII. Vidomosti Verxovnoyi Rady`Ukrayiny`. URL: https:// zakon.rada.gov.ua/.

2. Bocharov, A. V. (2006). Osnovnyye nauchnyye metody v istoricheskom issledovanii: Varianty strukturno-diakhronnogo analiza. Tomsk.

3. Vorobjov, G. P. (2014). Stvorennya ta rozvy`tok Suxoputny`x vijs`k Zbrojny`x Sy`1 Ukrayiny` (1991 - 2005 rr.). [Avtoref. dy`s. kand. ist. nauk]. Nacz. un-t oborony` Ukrayiny` im. I. Chernyaxovs `kogo. Kyiv.

4. Vytyah z istorychnoyi dovidky Upravlinnya kadriv MOU za period 1991 - 1992 rr. GDA MO Ukrayiny` (Galuz. derzh. arxiv Min. obor. Ukr.). F. 3501. Op. 17713. Sp.79.

5. Dashkevych, O. I. (2012). Metod periodyzatsiyi yak instrument istorychnoho doslidzhennya diyal'nosti kadrovykh orhaniv Zbroynykh Syl Ukrayiny z pytan' komplektuvannya posad vyshchoho ofitsers'koho skladu (1991 - 2011). Voyenno-istory`chny`j visny`k. 3 (5). 62-75.

6. Dashkevych, O. I. (2015). Vyshchyy ofitsers'kyy korpus: istoriya stvorennya ta komplektuvannya. (s.s. 167-285). Vinny”cya : "TD “Edel'vej i K”".

7. Dumenko, M. P. (2019). Funktsionuvannya sluzhb (pidrozdiliv) personalu Zbroynykh Syl Ukrayiny u 2011 - 2018 rokakh v umovakh myrnoho chasu ta osoblyvoho periodu. Voyenno-istory `chny $\mathrm{j}$ visny`k. 34 (4). 128-139.

8. Istorychna dovidka za 1991 - 2001 roky. GDA MO Ukrayiny` (Galuz. derzh. arxiv Min. obor. Ukr.). F. 3501. Op. 48085. Sp. 136.

9. Knyha shtatno-posadovoho obliku ofitsers'koho skladu ta praporshchykiv Holovnoho upravlinnya kadriv MOU za 1999 - 2001 rr. GDA MO Ukrayiny` (Galuz. derzh. arxiv Min. obor. Ukr.). F. 3501. Op. 48732 . Sp. 74.

10. Knyha shtatno-posadovoho obliku ofitsers'koho skladu ta praporshchykiv Holovnoho upravlinnya kadriv MOU za 2001 - 2004 rr. GDA MO Ukrayiny` (Galuz. derzh. arxiv Min. obor. Ukr.). F. 3501. Op. 48732. Sp. 32.

11. Kradin, N. N., Korotayev, A. V. \& Grinin, L. Ye. (2014). Teoriya i metodologiya istorii. Volgograd : Uchy`tel. 
12. Kuz'muk, O. I. (2011). Evolyutsiya struktury Zbroynykh Syl Ukrayiny (1991 - 2011 rr.). Viys'kovo-naukovyy visnyk. 16. 47-63.

13. Levyk, B. S. (2012). Viys'kovo-politychne zabezpechennya stanovlennya Zbroynykh Syl Ukrayiny 1991 - 1992 rr. (za materialamy Derzhavnoho haluzevoho arkhivu Ministerstva oborony Ukrayiny). Analitychno-informatsiynyy zhurnal "Skhid". 3. 96-102.

14. Mashtalir, V. V. (2009). Do istoriyi stvorennya normatyvno-pravovoyi bazy rehulyuvannya diyal'nosti ofitsers'koho skladu Zbroynykh Syl Ukrayiny. Zbirn. nauk. prats' "Pytannya istoriyi nauky i tekhniky". 2 (10). 22-24.

15. Nashy`vochnikov, O. O. (2016). Stvorennya osnov Vijs`kovo-Mors `ky`x Sy`1 Ukrayiny` (1991 - 1994 rr.). [Avtoref. dy`s. kand. ist. nauk]. Nacz. un-t oborony` Ukrayiny`im. I. Chernyaxovs`kogo. Kyiv.

16. Pokoty`lo, O. I. (2012). Stvorennya Zbrojny`x Sy`1 Ukrayiny`: istoriografiya. [Avtoref. dy`s. kand. ist. nauk]. Nacz. un-t oborony` Ukrayiny`. Kyiv.

17. Segeda, S. P. (2013). Ukrayins'ka viys'kova presa yak chynnyk natsional'noho viys'kovoho budivnytstva (XX - pochatok XXI stolittya). [Avtoref. dys. d-ra ist. nauk]. Nacz. un-t oborony` Ukrayiny` im. I. Chernyaxovs'kogo. Kyiv.

18. Sokal’, I. I. (2004). Stvorennya sy`stemy` proty`povitryanoyi oborony` Ukrayiny` (1991 2000 rr.): istory`chny`j aspekt. [Avtoref. dy`s. kand. ist. nauk]. Nacional’na akademiya oborony` Ukrayiny`. Kyiv.

19. Shevchuk, V. P. (2019). Istoriografiya stvorennya ta rozvy`tku Zbrojny`x Sy`l Ukrayiny` v 1991-2014 rokax. Voyenno-istory`chny’j visny`k. 31 (1).

\author{
Drok $\boldsymbol{L} . \boldsymbol{V}$., lecturer of the \\ department of military training \\ National Defence University \\ of Ukraine named after Ivan \\ Cherniakhovskyi
}

\title{
MAIN STAGES OF OFFICER CORPS OF THE ARMED FORCES OF UKRAINE FORMATION
}

The study reveals the historical process of forming the officers' capabilities of the Armed Forces of Ukraine from 1992 to 2020. The research identified five stages of formation of the officer corps and their names, conducted a statistical analysis of the number of position's officers of the National Armed Forces from 1992 to 2020, determined the chronological framework of each stage, described the dynamics of changes in the number of officers in each stage, calculated the annual average changes in the number of position's officers at each stage, reveals the essence of tendencies and 
priorities of activity of the public authorities and military management in matters of formation of officers in certain chronological frames.

Mathematical and statistical analysis made it possible to extend the periodization of the stages offormation of the officer corps of the Armed Forces of Ukraine, which became a fundamentally new approach to determining the problems of formation of officers of the Armed Forces of Ukraine.

The study of Ukrainian legislation in the military sphere, archival materials and sources of the Defense Ministry of Ukraine, orders of the Chief of the Defense Ministry of Ukraine, historical scientific materials allowed to consider the course of events related to the formation of the officer corps of the Armed Forces of Ukraine in certain chronological frameworks.

The results of the analysis of the number of officer positions explain the historical conditions that contributed to the formation of a professional component of our army - the officer corps of the Armed Forces of Ukraine and can serve to address the issue of determining the quantitative performance of officers in the construction of a modern Ukrainian army.

Keywords: officer corps, number of officer positions, Armed Forces of Ukraine. 